\title{
The mother and her ancestral face. A commentary on Iatmul iconography
}

\section{Christian Kaufmann}

\section{(2) OpenEdition \\ 12 Journals}

Electronic version

URL: http://journals.openedition.org/jso/6182

DOI: $10.4000 /$ jso.6182

ISSN: $1760-7256$

Publisher

Société des océanistes

\section{Printed version}

Date of publication: 15 December 2010

Number of pages: 173-190

ISBN: 978-2-85430-027-7

ISSN: 0300-953x

Electronic reference

Christian Kaufmann, "The mother and her ancestral face. A commentary on latmul iconography », Journal de la Société des Océanistes [Online], 130-131 | 2010, Online since 15 December 2013,

connection on 10 June 2020. URL : http://journals.openedition.org/jso/6182 ; DOI : https://doi.org/ $10.4000 /$ jso.6182 


\title{
The mother and her ancestral face - a commentary on Iatmul iconography
}

by

\author{
Christian KAUFMANN*
}

\begin{abstract}
Visually effective symbolization in Iatmul society is reviewed, starting from observations by Bernard Juillerat on the role of the mother in real as well as in symbolic relationships. Ceremonial acts of women and men in the context of naven rituals, and iconological representation anchored in initiatory knowledge are shown to be linked. Performing renders knowledge, services, material objects such as valuables or masks, i.e. cultural entities with a symbolic value, openly accessible for all parties concerned. They become the issue of exchange at specific occasions, enhancing the gendered roles of mother or elder sibling and their complementing actors, child or younger sibling.
\end{abstract}

KeYwORDs: Middle Sepik art, naven rite, agency of women, performing as ancestors and gender, physical objects as visual transmitters of implicit knowledge

\section{RÉSUMÉ}

L'expression visuelle des valeurs symboliques dans la société iatmul est reconsidérée, en partant d'observations de Bernard Juillerat sur le rôle de la mère. Sont mis en évidence les liens entre la façon de jouer les rôles, réels et symboliques, de mère, oncle maternel et neveu, aîné et cadet, à travers les rituels naven, et les représentations ancestrales matérialisées par des æuvres fondées sur le savoir initiatique des hommes. Les rites publics rendent accessibles à tous les savoir-faire, les prestations ainsi que des objets spécifiques y compris des masques, c'està-dire des entités culturelles à valeur symbolique. Leur présentation généralise l'importance des acteurs et de leurs partenaires complémentaires.

MotS-CLÉS: Art du moyen Sepik, cérémonies du naven, participation des femmes, représentation ancestrale et rôles sexués, parcours d'objets usuels visualisant des savoirs cachés «In my preliminary account of the culture I stated that while "the morphology of the
social" is patrilineal, the "sentiment" of the people is preponderantly matrilineal.»

This paper is about objects and visual knowledge revealed by things in several instances of Iatmul ceremonial context. Its aim is to reconstruct from the ethnographical record knowledge partly lost - this in itself might be a problematic approach, which, however, seems to me at least worth trying. In concentrating on non-secret knowledge, this approach aims at respecting the intention of present-day communi- ties (or «collections») of initiated Iatmul men, to preserve these fragile distinctions (Moutu, 2007: 102-105).

I shall start from an approach that Bernard Juillerat developed in the mid 1990s and published in 1999. In a close reading of Gregory Bateson's groundbreaking book on naven ceremonies, he was able to develop a comprehensive view of his own findings from the analysis of

* Honorary Research Associate, Sainsbury Research Unit, University of East Anglia (Norwich, UK) and Basel (Switzerland), chrkauf@yahoo.com 
orientation to life in Yafar society (West Sepik, Papua New Guinea) with more recent views of how Iatmul (East Sepik, Papua New Guinea) live their orientation of life. Juillerat built on the study produced by Carlo Severi and Michael Houseman (1994), who had systematically elaborated on naven from a conference held in 1989 and had included further documentary evidence established by Milan Stanek and Florence Weiss. Juillerat restudied notably further details contributed by F. Weiss in conjunction with Fritz Morgenthaler, Marco Morgenthaler and Stanek as well as by others. Juillerat was also able to include references to Eric Silverman's description and analysis of relevant events and views form the easternmost Iatmul village of Tambunum, unpublished yet at that time (Bateson, 1958 [1936]; Juillerat 1999, Morgenthaler et al., 1984, 1987; Houseman and Severi,1994, 1998; Moutu, n.d. [2006]; Herle and Moutu, 2004; Silverman, 2001). Today, while Andrew Moutu has already published elements of his groundbreaking new attempt at a close reading, based on recent fieldwork, it seems fair to renew Juillerat's thrust and to follow up also, like Moutu, on Marilyn Strathern's lead idea on exchange relationships (Herle and Moutu, 2004; Moutu n.d. [2006]; Strathern, 1988, 2004; Weiss and Stanek, 2006). It is easy to see why Moutu is critical both of Silverman's and of Juillerat's interpretations in as far as they seem to him as a Papua New Guinean anthropologist to rely too heavily on a psychoanalytical perspective, rooted in European classificatory categories. However, it seems to me that Moutu is dismissing Juillerat's approach too quickly as should become evident in the following. I would like to focus in retrospect on the extraordinary role which Iatmul people of the pre-2000 period conferred upon material objects for marking gendered statements in some of their social relationships, often in order to visually enhance an important aspect in the exchange of knowledge or services emanating from very specific relationships between individuals.

\section{Environmental context of gendered roles}

The Sepik River area in general, and more specifically the parts along its middle and lower course, offered environmental facilities that would allow women to develop agency on a level unknown in New Guinea highland societies where subsistence is based on reproductive hor- ticulture cum pig raising. It were these latter societies that became the stars in the Great man/ Big man debate; as a consequence large bits of Sepik ethnography, including Juillerat's classical texts on the Yafar people, Les enfants du sang and Edipe chasseur, hardly penetrated into classroom anthropology; the Yafar are living way off from the upper courses of the main river in yet a different environment (Juillerat, 1986$1996^{1}$ ).

On the Sepik River ox-bow lakes, earlier formed by the river but then detached from its main course, provide an ideal set-up for varied and numerous populations of fish to be developed, and further away from the river freshwater swamps are home to extended stands of sago palms, a major source of starch that would be continually available. Both fields developed into the domain of basic female activities like fishing and gathering shrimps as well as scraping sago pith and then obtaining sago starch from the pith through a washing process, providing thus the real base of living to the villages living next to the river. Local specialization of those villages living closer to sago stands (and claiming ownership on them) and those living closer to fishing grounds (and claiming ownership over the latter) may even have lead, as in the area of the middle course of the Sepik, to a firmly installed system of regular markets where fish from the river were and still are being exchanged against cakes of sago flour. Women from the river villages travel regularly and on their own initiative to the market spots. However, even in those river villages most dependent on women playing their economical roles very actively, men are very much in control of the ritual power of each village, and, as a consequence, of representing its physical strength. Underlying this we find the notion that there is nevertheless a maternal source to this power, and in fact rituals play at rendering this relationship between men and mothers visible.

Two observations might help to frame the problem: First, for a considerable time span before Europeans arrived, societies in the Sepik area at large produced a variety of items of material culture well beyond the needs of subsistence production in a technical sense. The degree of variations seems to have been highest in the village societies oriented on the river, feeding basically on fish and sago. This considerable output was, if not coming from the hands of men, at least controlled by men through the mechanics of a basically patrilineal social organization (with the

1. See for the Yangis rituals also Juillerat ed. (1992), including the follow up discussion with, among others, A. Gell, R. Wagner, A. Strathern and R. Werbner, the later two on regional comparisons, as well as Juillerat (1991). 
exception of Lower Sepik societies from Biwat to Murik, see Lipset, 1997). Second, none of the Sepik societies, as far as we are aware of, did "indulge" in competitive exchange of commodities on a notable level (as in the scenario of Enga tee, Melpa moka etc.), though, in neighbouring societies producing yams the exchange of these products of intensive gardening, vital for keeping the tuberous plants and their crops safe and sane, reached quite spectacular levels. Even there, the product was considered more in terms of its bodily quality, i.e. as a manifestation of ancestral presence, made possibly through a close cooperation of ritually specialized men and their female partners, rather than as a material good the giving of which would create asymmetrical dependencies. Yet, the display and intervillage exchange of some of the Abelam long yams certainly was competitive - the salient point here being that each long yam tuber of Dioscorea alata produced by a specialized Abelam planter with his wife's hidden support is as much a representational work of art as its equivalent carved in wood, the ngwalndu carving, produced by men alone (Forge, 1966; HauserSchäublin, 1986; Coupaye, 2009a and b; Roscoe, 1995).

Could one motivation to produce a vast array of visual representations across the Sepik area then be found in a cultural drive to strike a balance between gendered roles in society? On the male side these could be described, on the base of ethnographical knowledge, e.g. as ritual management, ideological dominance or displaying physical strength, and on the female side, as the management of subsistence oriented activities and of nurture or the display of physical fertility $^{2}$. While in the past, creating and controlling visual representations assured for the male part a high visibility, the female part was kept less conspicuous. The impact of ceremonial houses (Hauser-Schäublin, 1989), with their extensive outfit of figurative and non-figurative representationalelements, of ritual gear, including a broad variety of mask costumes and their heads or faces, or of canoes, and also of household equipment such as carved suspension hooks, all made by men, was certainly overwhelming.

On the other hand, the most visible products created by women were, for the area we are most concerned with and children apart, pottery vessels for every-day use, decorated net bags or plaited bags as well as capes protecting against sun and rain. Perhaps, one could ask, do hidden links between the male and female creative acti- vities indeed form the core of the secrecy enshrined in ritual performances? In order to understand these questions we need to learn to see how, especially in middle Sepik, views about matters of life and of gendered roles are subjected to steadily ongoing transformational processes, overriding even the barriers of biological sex ${ }^{3}$.

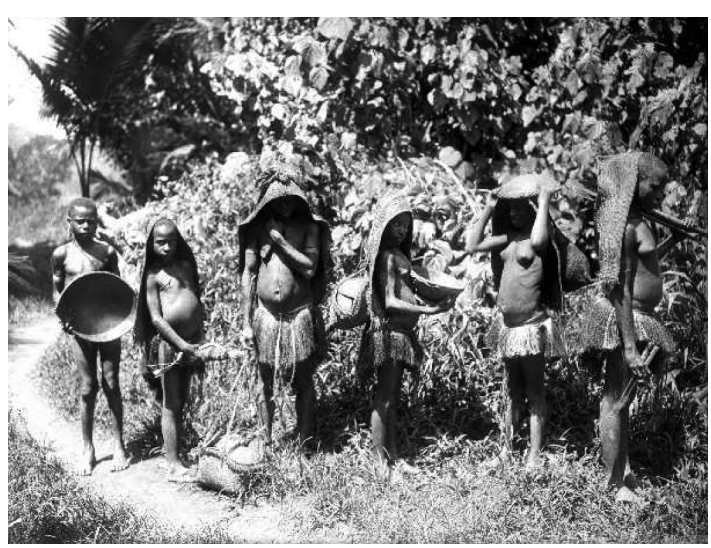

Рното 1. - Women on their way to or from a pottery market near Aibom village, with their plaited capes protecting against sun and rain, ceramic ware and mats (CFelix Speiser, 1930, Archive Museum der Kulturen Basel - inv.nr. (F) $\mathrm{Vb} 759)$

It was Bernard Juillerat who was able to show just how such relationships among the Yafar in the West Sepik Province are being objectified, i.e. made visible (and partly also audible) in ritual performance, using mainly temporarily decorated human bodies, a few solid objects like arrows and hand held drums together with paraphernalia just made for temporary use (Juillerat, 1986, 1992, 2002a). Juillerat's point being that the ritual performance enhanced values that were also recognized by Yafar individuals as underlying their inter-personal relationships. We should not expect otherwise for the middle Sepik area. We shall thus move about on a triangular field of analysis determined by ritual relationships, emotional relationships as well as relationships to objects, all subjected to transformation.

\section{Which Iatmul relationships are we looking for?}

Focusing on middle Sepik art and the ethos of those societies I am well aware of the danger of again pronouncing «categorial fallacies» (Moutu, n.d.: 19) in trying to link specific types of objects to exchange gifts in the sense of knowledge and services rendered in the context

2. Meeker, Barlow and Lipset (1986) started from a similar idea, but followed a different agenda.

3. The wider issue of gendered artefacts in New Guinea is not discussed here, see, among others, Strathern (1988). 
of naven - bound relationships. These will be the focus of the following explorations.

In general, naven ceremonies of all kinds mark the return of a successful junior member of the family to his or her mother, after having for the first time achieved performing a relevant task. This could apply to a girl having done a first fishing tour on her own, or a visit to the sago market, or to a boy or a girl having obtained a school or university degree. A boy's proper achievement could range from having carved his first canoe or having won a soccer match to having passed initiation or having performed successfully in a specific ritual. While it can be said that naven ceremonies should be considered as being mainly lineage or clan oriented, the relationship between a son, his mother and his mother's brother apparently is not restricted to either one of the mother's or father's clan public domains.

It is worth pointing out that Juillerat's point of departure which rests in a text by Florence Weiss (now also available in English, Weiss and Stanek, 2006) and to which we will turn shortly, was not only that the baby child looked back to his mother, but that the mother in the private naven performed gives to her relationship with the child a new twist, thus solidifying an ambivalent relationship. Juillerat also draws attention to the permanence of the role of the absent, the father, which is only partly expressed by the presence of the father's sister, the yau, and starts to explore the contrasts in roles of elder/younger siblingship (Juillerat, 1999: 155-156, 163, 166, 168-170). His main concern is with how individuals interrelate with each other in really complex ways, thus showing how multifaceted their grown-up personalities are. To focus thus on interactions between individuals seems to me to be fundamentally different from an approach at classifying personalities according to simplified role models.

Hence, the prominence given to the return to the mother as observed and explained by an experienced Iatmul woman of Palimbei village. This return became the key motive to Florence Weiss' 1979 interpretation of naven. Andrew Moutu reports that his Iatmul tutor(s) of Kanganamun village saw in 2001 the key in the elder brother/younger brother relationship that is not only at play between siblings, both sexes confounded, but also by extension between members of age classes and generational classes to which this model is also being applied as of today. In fact, he says this view also applies to any Iatmul individual keeping together life and death, the ultimate pair of siblings, evidently as long as the individual is still alive. With the return of the younger the elder sibling becomes invisible (Moutu, n.d. [2006], Herle and Moutu, 2004). Moutu makes a very convincing case for his radically new approach. In the details of the argument, the difference may reflect a shift from the vision argued by female Iatmul partners in field work (Weiss, 1987, 2006) to one argued by men. Another shift may have taken place over time in the mind sets of both, the anthropologists (in regard to the study of gendered roles, quite new in the 1970s) as well as of populations in the Iatmul villages (with fundamental changes between 1975 and 2001).

One has also to remember that even the modern Kanganamun vision of naven as related by Moutu (Moutu n.d. [2006]) is due to classifications that are established by the grouping of initiatory classes into two ritual moieties (Bateson, 1958: 245; Herle and Moutu, 2004: 10, 24-31). Initiation in this view is a procedure where members of an elder brother line initiate the incoming members of a younger brother line in a way that physical fathers and sons belong always to the same initiatory line A or B. Each line constitutes a moiety, though in terms of filiation physical fathers and sons belong to opposed generational classes, aligning Ego, his grandfather and his grandson in one class, and Ego's father and Ego's son in the other. The initiatory lines interlock according to a principle of relative age: age stages, paired 1-2, 3-4 etc. to 7-8 or 9-10, are divided into those of the «elder brother line» (A) sub-group and those of the «younger brother line» (B) sub-group, forming classes $1 \mathrm{~A}$ and $2 \mathrm{~B}, 3 \mathrm{~A}$ and $4 \mathrm{~B}$ etc. ${ }^{4}$ Thus, members of $1 \mathrm{~A}$, as sub-group of the fathers, act by applying scarifications onto the bodies of $4 \mathrm{~B}$, while $2 \mathrm{~B}$ members act on $3 \mathrm{~A}$, etc. In each of these individual relationships a senior and a junior partner are linked, addressing each other as elder brother, nyamun, and younger brother, suambu, respectively 5 .

However, it is important to note that there was formerly a swinging over of the system which was referred to already by Bateson as a logic functional requirement (Bateson, 1932: 433, Bateson, 1958: 245), making the younger brother line B becoming in toto the elder brother line A. In other words, this ritual was about acknowledging that the kamblal, i.e. all the men of the son's generation of groups 3A and 4B (and possible

4. I follow in the numbering the basic scheme of Bateson (1958: 245), without his doubling-up, while Herle and Moutu (2004: 10), Houseman and Severi (1998), and Schmid and Kocher-Schmid (1992) have followed a different logic each.

5. Moutu writes shuambu (Moutu, n.d.), Bateson tshuambo. 
annual sub-sub groups), who had passed through initiation together and who still occupied the tegal men's house, had eventually wretched power from their initiators and thus were now prevailing as the masters of all high level ceremonial houses (ngeko). Only by this main generational rite would the individual transformations of younger brother initiates, suambu alambandi into elder brother initiates, nyamunalambandi become fully endorsed. Thus the initiation classes $2 \mathrm{~B}, 4 \mathrm{~B}, 6 \mathrm{~B}$, and $8 \mathrm{~B}$ of the younger brother moiety would be officially transformed into classes $-0 \mathrm{~A}, 1 \mathrm{~A}, 3 \mathrm{~A}, 5 \mathrm{~A}$ of the elder brother moiety, while new $7 \mathrm{~A}$ and $8 \mathrm{~B}$ would receive the younger children, originally grouped into the mbore youth house (Schmid and KocherSchmid, 1992: 25). This, in the past, led to a complete renewal of the system, getting it back into tune with the physical age of its members in each age group. However, this practice stopped taking place around 1929 in the Central Iatmul group of villages, an omission which led to a blockage, weakening the system as a functional entity. It also means that objects specifically used in these rituals became dysfunctional.

The resulting distortion of the old system forced Iatmul experts to find other solutions (Schmid and Kocher-Schmid, 1992; KocherSchmid, n.d.). For the Nyaura-Iatmul, Wassmann reported that the reversal somehow was still being achieved in the 1970s (Wassmann,
1991: 32). According to Moutu there is now a complete split between the cosmological moieties on one side, and the ritual moieties active in initiation on the other. While the former provide the structure for grouping lineages and totemic clans into operational units within the village at large, thus establishing generational groupings identifying fathers with their grandsons, and sons with their grandfathers, the latter most effectively create bonds between individuals sharing experiences and restricted knowledge. Opinions diverge on whether this split might have applied in the past to all three Iatmul regional groups. In 1984 Cherubim Dambui of Timbunke village (Woliagwi or Eastern Iatmul) maintained that the overall balance of the system, unifying initiation moieties and totemic moieties in an unspecified way, was indeed in need to be re-implemented then and there ${ }^{6}$. Dambui identified at that time in European museums two types of carvings, necessary to perform the rite, one a pair of snake carvings, about $4 \mathrm{~m}$ in length, in the Bühler collection, and the second, a very special type of water drum in the Roesicke collection? Both types show an evident homology to elder brother/younger brother pairs; the object types are mentioned or alluded to in the survey of rituals for Yentshan and Palimbei villages, explained by the Iatmul experts of that time to J. Schmid in 1972-1973 (Schmid and Kocher-Schmid, 1992: 56-58, 66-70 referring to wakin mbangu).

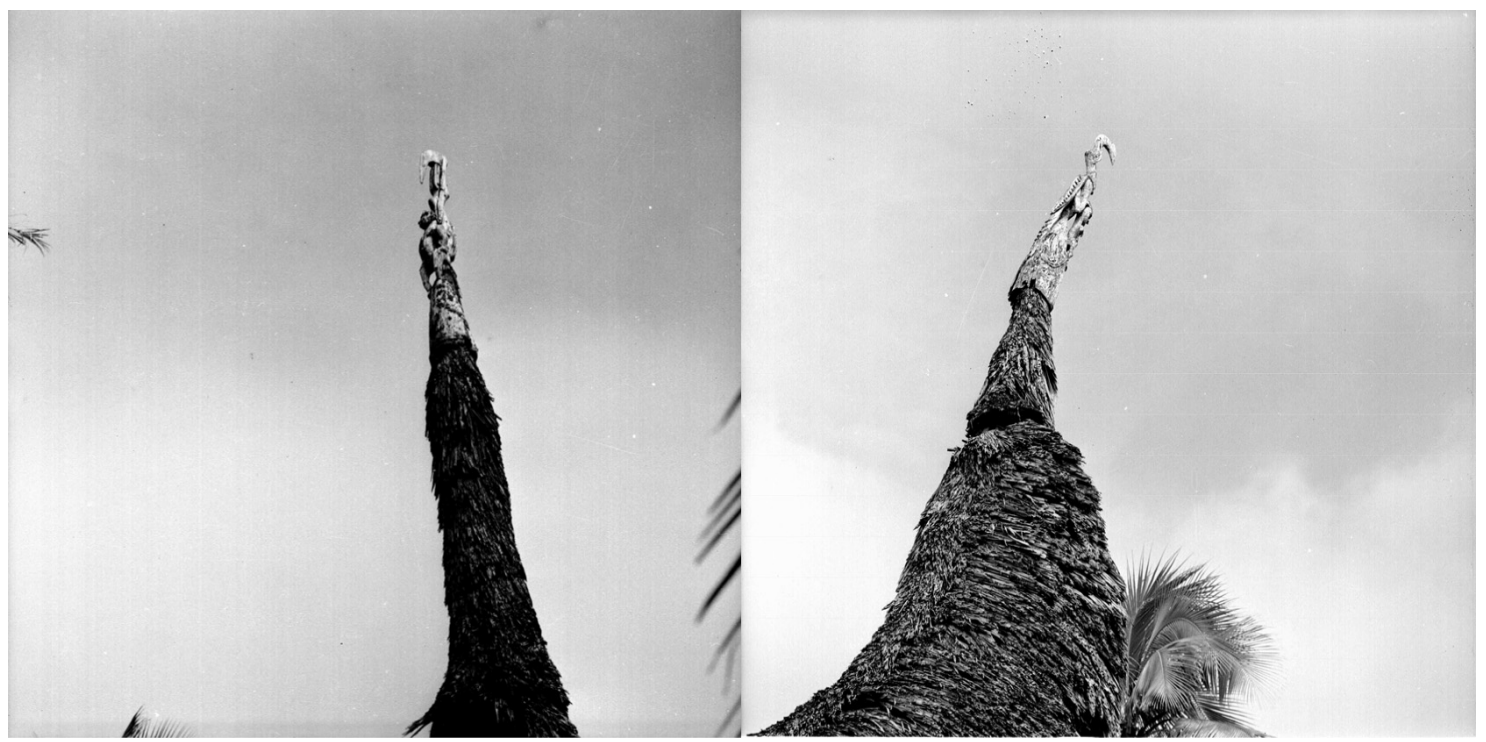

Рнотоs 2a-b. - Carved finial of a ceremonial house, ngeko; carved finial at opposite end of ceremonial house; both carvings represent ngauwi, a pair of eagles shown in association with their mother, probably in Kanganamun village (CRené Gardi, 1956, Archive Museum der Kulturen Basel, inv.nr. (F)Vb 13074 \& (F) Vb 13073)

6. Father Cherubim Dambui in two oral communications in the then Museum für Völkerkunde Basel and in the Museum für Völkerkunde Berlin in August 1984 during the Sepik Heritage conference and the excursion to visit museums in Germany (see also Kaufmann, 1990: 593).

7. Basel Inv.nos. Vb 14718 and Vb 14719 from Kararau village, cf. Kelm 1966, I, nos. 36,37, and Berlin Kelm 1966, I, no. 153. 
Where there are brothers there must be a mother, too. Indeed, the most prominent pair of brothers in Iatmul mythology are the two eagles ${ }^{8}$. Their mother is the primeval ancestress, sister to the primeval ancestor. Although their names vary from clan to clan, Kabiragwa for her, Mangisaun for him may be used here as type reference, the individual versions being referred to in many documented versions.

Of course the elder brother-younger brother relationship plays a very critical role in many other mythical explanations of world views, too. It could well be that splitting the ritual view, focusing on initiation as a ritual of unification, from the level of village segmentation based on cosmological and historical references in clanowned traditions, is the answer given by active Iatmul (Kanganamun) ritual experts to the underlying problem (Herle and Moutu, 2004: 10; Moutu, n.d.).

Up to this point we have encountered several types of objects which have played or may have played a role in a naven context; the latter was male gendered in Bateson's approach. Does widening this approach improve our visions?

\section{Displaying knowledge, that unites-a way of gifting}

The totemic system, by itself, tends to cut up not only the layout of the village but the whole landscape into clan lots. Even the tracing of knowledge in the system of opposing a sun (and father) moiety to a mother (and earth) moiety, though ultimately complementing each other, seems rather divisive. These divisions, reenacted even in daily life again and again - hence Bateson's focus on relationships expressing opposing sets of values and on schismogenesis -, call indeed for a band of unifying actions. While initiation procedures recreate a sort of malebiased primeval unity across the socially divisive principles such as totemic descent (Herle and Moutu, 2004: 15, 24), or the father-son dichotomy, the exchange of gifts in the largest possible sense (including the giving of knowledge or service) as discussed by Marilyn Strathern (Strathern, 1988) and Maurice Godelier (1986-1996) would offer, it seems to me, an efficient way of rendering relationships visible. I suggest that looking more intensely at what objects «do» in the context of naven could be helpful to clarify our vision of Iatmul practice.

According to the view of Carlo Severi and Michael Houseman (1998) this unifying role, is indeed played by the interrelated segments of the naven ritual. By being reinvented within limits each time its performance seems desirable, it serves as a tool to handle the relationships between mother and her child, between notably a son and his real as well as his classificatory mother's brother. More importantly the ritual helps defining relationships between an individual and his classificatory father's sister, and, by extension, between at least two exogamous patrilineages (or clans). In practicing naven as ritual, the Iatmul according to Severi and Houseman are constantly re-implementing crucial relationships, including those that help to identify potential marriage partners. It is the underlying procedural logic of transformation rather than separation that makes naven qualify as ritual, according to the two authors quoted. Houseman and Severi, based on evidence from F. Weiss and M. Stanek, do indeed refer to the use of objects and especially of masks in conjunction with naven rituals, though both are seen rather as essential tools than as containers for gifts of knowledge. Andrew Moutu in turn, based on new evidence from his fieldwork, is arguing for a more simplified view of naven ceremonies, which in his perspective all implement, in one or the other way, the return of the younger, more aggressive, more exalted brother after a period of split.

Returning thus from the larger stage set to the narrower one, positioned at the opposite end, where individual relationships are at stake, we have to accept that, until proof to the contrary, Magindaua's view of 1979 and Andrew Moutu's view of 2001 are not mutually exclusive. For all we know from Palimbei village, the naven relationship links a mother, nyame (and by extension her brother, who together represent the nucleus of the maternal clan) to her child (and by extension to the child's father and father's sister, i.e. the nucleus of the paternal clan). Because of the transformational rules at play in Iatmul society, this same relationship can be expressed as one linking the mother's brother (wau) to the sister's son (laua) or daughter, and again as a link between a father's sister (yau) and her brother's child (kanggut). The model is applied beyond the links established through direct male in-laws (tawontu, WB).

At marriage substantial gifts of bridewealth (to set the bride free to move from her own paternal clan to her husband's paternal clan) and of dowry (enabling the bride as an individual to set up her own existence as a productive, yet co-opted member of her husband's clan 
using her own fishing and household gear) were set in motion (Hauser-Schäublin, 1977: 79-97, 1985: 522, 526 cf. Bateson photograph in Herle and Moutu, 2004: 16 below). The bridewealth traditionally consisted of shell valuables as well as of netbags charged with symbolical meaning (vagina); after 1950 modern currency replaced the shell-valuables, though partly only in the dowry. Shell valuables are associated with the male gender. Those on the side of the bride's clan, who did not receive parts of the bridewealth, would later qualify to become the classificatory mother's brothers, wau, so important for the future children of the bride, their laua. The special personal name with the mother's clan ending and a coconut are given to the child by his wau. These classificatory wau-laua relationships may even be knit in a way to link certain clans closer together, making them more efficient in mustering the work force needed to do joint construction work on the ceremonial house (Bateson, 1958:95-96; Severi and Houseman, 1998: 80-88). Laua in due course shall become as adults as indispensable to the wau as he is in earlier life to them: laua are supposed to carve ancestral figures and masks for them.

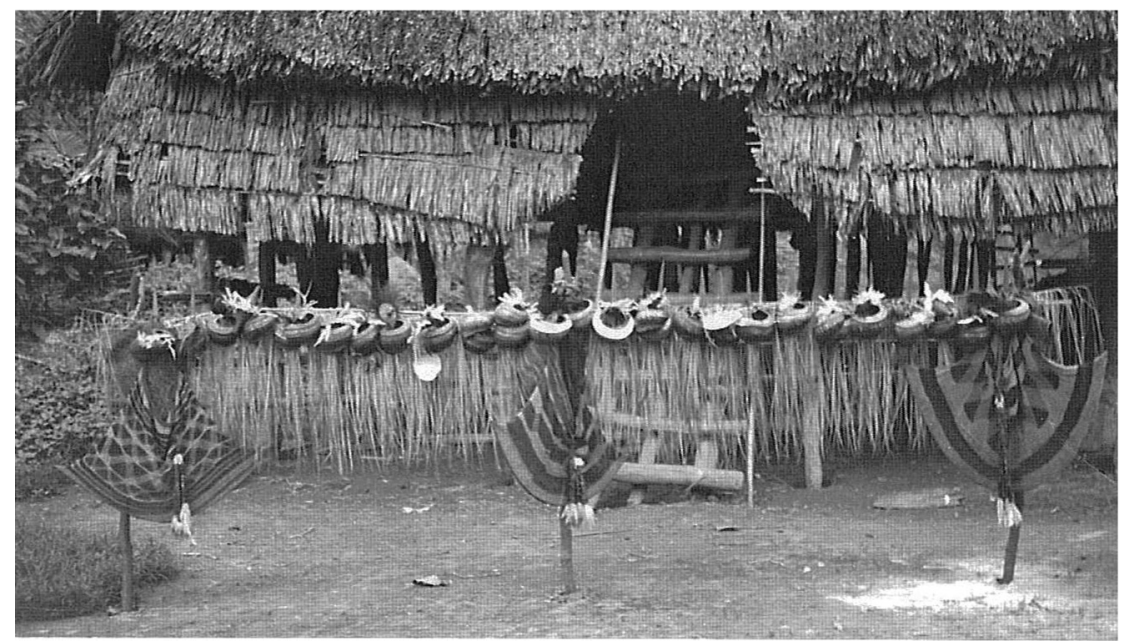

Рното 3. - Bridewealth presented to the bride's clan in Kanganamun (Photo Gregory Bateson. This image is copyright.

Reproduced by permission of University of Cambridge Museum of Archaeology and Anthropology, acc.no. P.16747 BAT)

That said, exchange matters became even more complicated from that point onwards. On the one hand there was and still is a constant flow of food being exchanged as described by A. Moutu who explains some of the underlying complex rules which pertain to a number of differentiated ways of tracing relationships. On the other hand, services provided were and still are of a very complex nature, too. As M. Strathern, discussing the mode of unmediated gift exchange (without physical objects being handed over) observes, gifts of knowledge or services, such as «the mother making her baby grow in her womb» (Strathern, 1988:179), may replace, wholly or partially, objects or goods 9 .

Now, this raises the question, already discussed by Weiss (Morgenthaler et al., 1984: 218228), to what extent does the unmediated gift exchange, including the transfer of knowledge, play a role in naven relationships? Such a transfer could consist in passing on secret names not to be revealed, or it could consist in revealing the visual knowledge of and about physical objects and what they were standing for (as in the case of masks). Of course, visual knowledge might be directed at partially revealing, and, quite at the same time, partially hiding some secrets, which it is useful to know. Whether such an explicit visual reference to objects, in the past, implied that at least some of the physical objects were wandering from one constituent in the relationship to the other, we do not know. Or, whether indeed in referring to objects it was only the knowledge about their visual impact that mattered, knowledge rendered accessible and transferable by visualizing certain aspects, while the object stayed put.

9. Gift here simply meaning «a thing given», therefore in return for a virtual thing given, such as a service or a bit of hidden knowledge, an object representing a symbol of value might be received, a transaction that only in a colonial, money driven view would be judged as buying. It is worth noting, though, that this sort of transaction is in Tok pisin, the Melanesian Pidgin, also referred to by the terms for pay (pe) and buying (peim). 


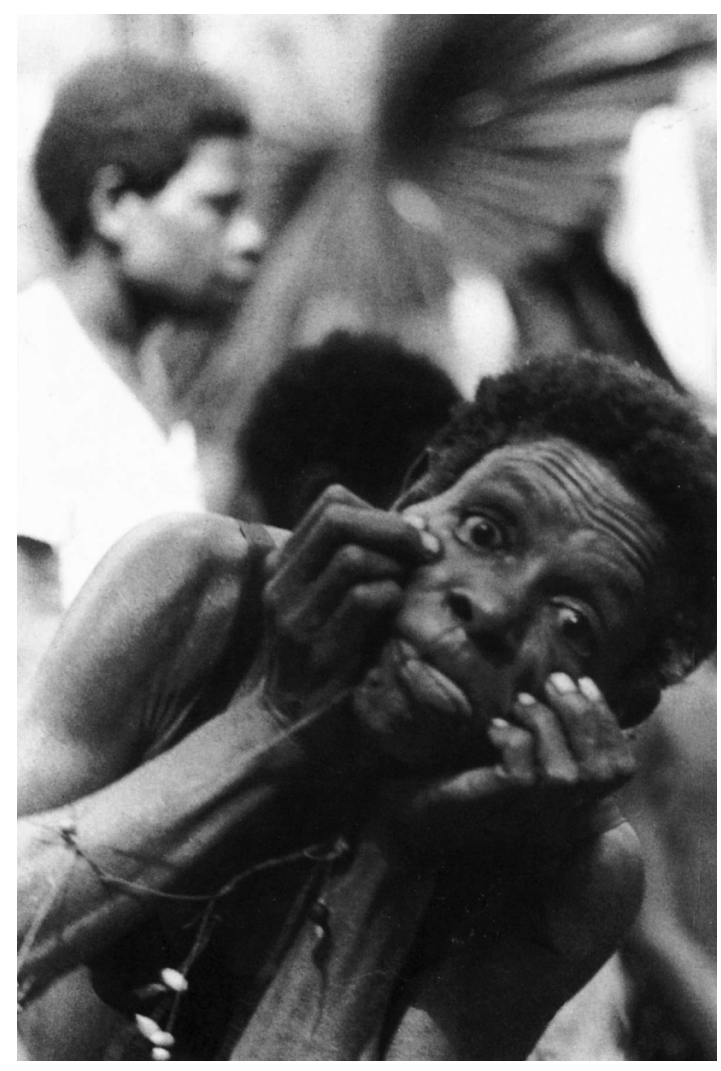

Рното 4. - A mother dancing naven for her child (CFlorence Weiss, 1974; reproduced by author's permission)

\section{Face to face with your ancestor}

In the behavioral sequence taking place between a mother and her child which served as our starting point, the very earliest naven a mother may practice for her child had been described by Weiss (in Weiss and Stanek, 2006) based on her immediate presence at the scene between Magindaua and her baby son in the following words:

«[...] I [Florence] sit here not having a clue [about a story just told to her]. Magindaua calls out to her baby. As he has done a few times before, he has crawled to the edge of the platform from where he could fall down. Suddenly, she rolls her eyes, sticks out her tongue, and wildly moves her torso and legs to and fro.

Florence: "Are you doing a naven?"

- Magindaua: "Yes, I am doing a naven."

- Florence: "Because the baby crawled away?"
- Magindaua: "Oh no. Because he looked back when I called out to him."

- Florence: "You do a naven because he looks back?"

- Magindaua: "Yes, he did look back."

- Florence: "But you do a naven when a girl catches her first fish or after completion of the initiation ritual or when somebody from far away returns to the village."

- Magindaua: "Yes, that's when we do a naven."

- Florence: "Does the girl who comes home with a fish or the young men after their initiation also look back?"

- Magindaua: "That is so."

- [Silence]» (Weiss, 2006: 61, see Photo 4 showing a mother doing the same facial gesture while dancing a naven)

In reconsidering the above reported interaction and dialogue with Magindaua, Weiss writes:

«She responded to this seemingly insignificant event with a few body gestures reminiscent of dance choreographies that I had seen in all elaborated naven performances. I found especially noteworthy that her facial expressions also came from the naven repertory. They represent the mythical mother who, in the imagination of Iatmul mythological culture, is always split into two aspects: the nurturing good mother and the devouring, powerful, dangerous mother. In the system of totemic names, these two aspects are for the Iatmul differentiated as the ancestral figures Ndanganagwi versus Ndumanagwi.» (Weiss, 2006: 62)

In fact, Magindaua, in a separate conversation demonstrates and confirms that the facial gesture from the naven repertory referred to the carved head on the upper part of the central house post inside the ceremonial house supporting the roof beam (not the much lower floor) ${ }^{10}$. Therefore this was, at least for Palimbei-Iatmul of the 1970s, visual knowledge accessible to a married woman. Magindaua claimed convincingly it was women's knowledge related to scenes from naven, and that the men, when carving this type of distorted face were unaware of the specific implication it carried in a naven context. Women had naven, men had initiation (Weiss, 2006: 68). Should we conclude from this, that both are about transformation?

10. Magindaua's statement in context: «Florence: ‘[...] When you explained the naven to me, we came upon a secret the men don't know anything about.' - Magindaua lies down stretching out on her back, sticks out her tongue as far as she can, opens her eyes widely and pulls down her lower lids with her fingers, shifts her hands behind her ears so that they stand out, lifts her arms and pulls up her legs. She demonstrates faces and gestures of the naven. - Magindaua: 'The carvings you are talking about [on the posts of the derelict men's house, with one of the figures sticking his tongue out] are scenes from naven.' - Florence: 'Your men don't know the 'look back' of the child, but you women do.' - Silence.» (Weiss, 2006: 66-67). 

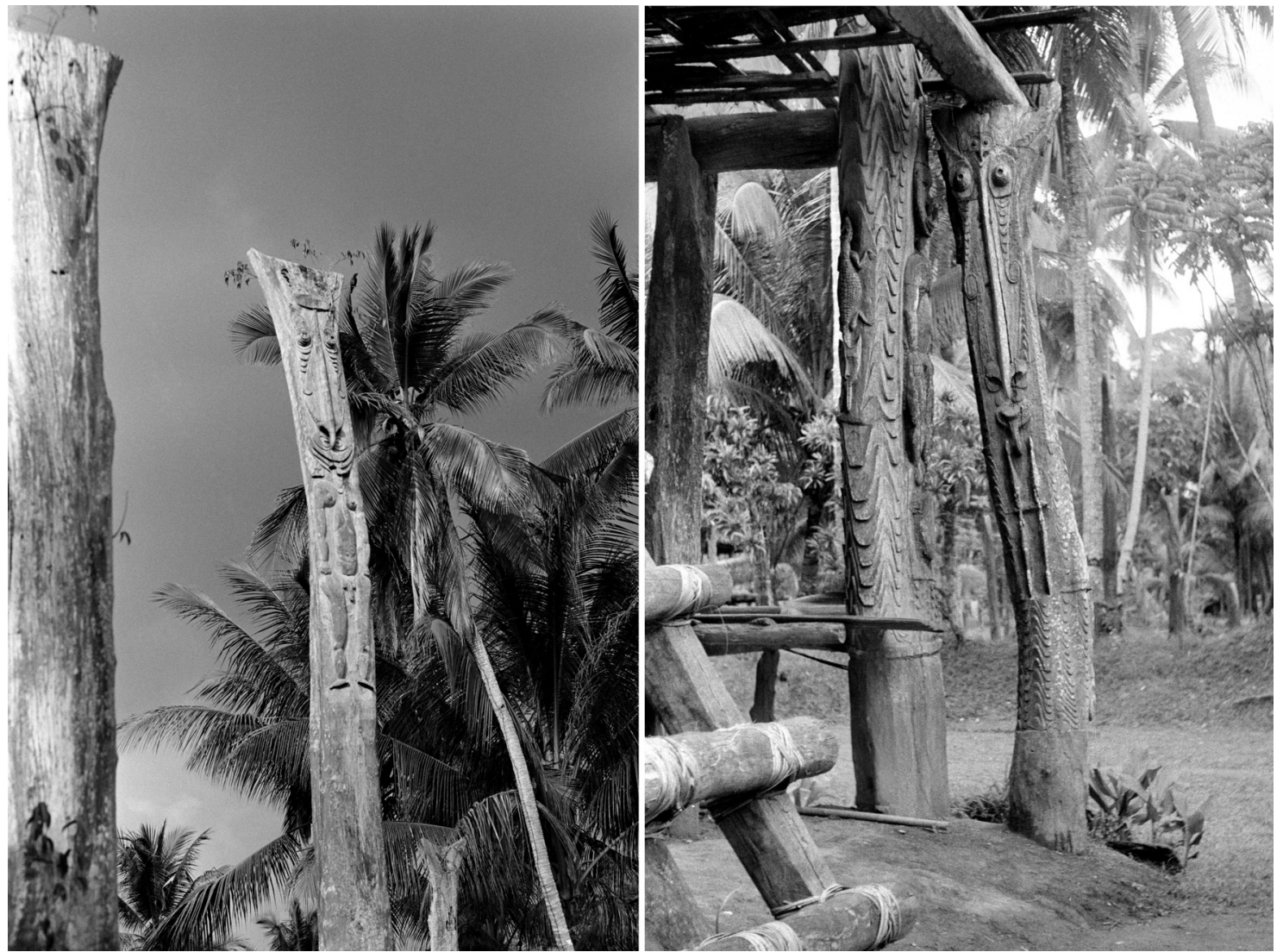

Рнотоs 5. - a. Central post of a ceremonial house, ngeko, awaiting reconstruction in Palimbei village 1973 (CFlorence Weiss 1973, Archive Museum der Kulturen Basel, inv.nr. (F)Vb 26236); b. Corner post for platform of Wolimbit ceremonial house,

Kanganamun village (CAlfred Bühler, 1956, Archive Museum der Kulturen Basel, inv.nr. (F)Vb 6964)

In showing her child this ancestral face through a gesture involving her own motherly face being deliberately distorted, to make it look like that of a principal ancestor - in fact by transforming herself temporarily into that bi-faceted ancestor (Weiss, 2006: 64) - she would render a service to her child. She meant to prepare the child for further revelations of knowledge by her brother (real or classificatory), the child's wau, as well as by other initiated men, including the child's father.

\section{The wakin ${ }^{11}$ mode of representation}

Magindaua claimed that the specific type of face originated from naven knowledge controlled by women. What does this imply? She visually and at least temporarily identifies with a maternal ancestral face according to her vision of naven. Gregory Bateson was told that the apparently similar face type on a smaller side post referred to a winsumbu, following Bateson's caption a wood spirit (Bateson, 1958: pl.VIIIA). For Magindaua's interpretation the wood spirit seems not to be a match. The central post is indeed embodying the main village ancestor as much as the cohort of peer posts embody his peers across the main clans (Wassmann, 1991: 29-32).

However, there is the well-known ambiguity that the house as a whole is the original ancestress, supporting, on the peaks of the gable her sons, the pair of aggressive, cannibalistic eagles. Among the Nyaura (western Iatmul) the ancestress is the sister of a primeval ancestor, Mangisaun (Wassmann, 1991: 176). Moreover, in a version of oral tradition collected at Soatmeli, the village from which all villages of the Nyaura and the Palimbei groups descended, this type of face on the main house post of the ceremonial house is linked to one of the first wakin spirits that could enter humans, Ndimbitmeli. As a child [!], Ndimbitmeli climbed up to the top of

11. Bateson (1958) writes wagan, Schmid and Kocher-Schmid (1992) write wakin, where «i» represents the schwa-sound (ə) - I use therefore wakin. 
the main post in the ceremonial house, in fact breaking through the roof. The wakin Ndimbitmeli had first possessed a dog and spoken through this animal. He now called out from his position on top of the post to his maternal relatives, asking them that they should call him by his rightful name - which they did, setting him free to jump down from the post and to go into the ground. He immediately entered a human being, speaking through him, and continuing to do so to this very day (Schmid and KocherSchmid, 1992: 19).

Ndimbitmeli was among the first wakin spirits that had reached the world of the humans by devouring all the skin, flesh and entrails of a man, leaving only his bones - these beings were aggressive snakes living in a hollow tree near Soatmeli and forming a bundle, ndimangwaran (Schmid and Kocher-Schmid, 1992: 66). The human beings were shown how to call the useful wakin by cutting a suspension hook from the tree, hanging up ten mother of pearl shells for each wakin, and also having areca nuts ready for them $^{12}$.

In conclusion, the carved face on the top of the house post could indeed be a primeval wakin's face, remembered for his links to his maternal ancestors. Immediately, an intriguing question arises: Are mothers doing through naven what wakin do for and through men, including initiation?

It is impossible to try to answer this question in the space available here. At least two lines of interpretation would need exploring; according to the first, representing ancestral beings in their wakin manifestation stresses both their aggressiveness and their readiness to support the humans, if called in to do so. Following Bateson wakin spirits can be grouped hierarchically and functionally. The main difficulty seems to be that the term wakin was often used in a very general sense on one hand - subsuming all sub-groups into one entity, that of rendering ancestral spirits - , and in a more restrictive approach on the other. Within the narrow sense functional subgroups of certain kinds of wakin spirits were defined, some of them very secret and powerful. There is also the record of a most prestigious public ceremony where a pair of wakin figures installed on the ceremonial ground and their human companions make their appearance (Bateson, 1932, 1958: 233, 236-237 and plates XVIIIB and XXVIIIA). One of Bateson's infor- mants said wakin are behind everything (Bateson, 1958: 237). On the base of further evidence assembled by Schmid from Yentshan, Kanganamun and Palimbei villages (Schmid and KocherSchmid, 1992: 17-19, 66-67), wakin can be seen as a way of being, more specifically they can be seen as the communicative aspect of ancestral beings (as the story of Ndimbitmeli has made clear). They emanate from the ancestral. They can be both helpful (they can be invoked with shell valuables) and dangerous (they strike an individual with death, fright or disease). If a wakin spirit gets into a human, normally a man, the individual will be speaking out this wakin's message in a distinct voice and with wild movements, first of the limbs, in the context of a shamanistic set-up. The human medium thus becomes bodily part of the ancestral being in question.

This communicative aspect on images representing ancestral beings, either carved or painted, is marked by wide-open eyes protruding from the centre of oval-shaped concentric planes, a small long nose, a protruding tongue, and, quite often, a row of superimposed semi-lunar shaped segments hanging below the face. A main distinction of the spirit beings underlying this face type would be between the protective elder brother-wandsimot and the pushy, aggressive, warring younger brother-wandsimot-wakin (Schmid and Kocher-Schmid, 1992: 16); to my present knowledge it seems possible that the distorted face refers rather to the aggressive younger brother variant of siblings.

A second approach however would follow another line of argument by accepting that Bateson's Iatmul male informants in the 1930s may have played down these signals of liminality by identifying the same face type as representing a wood spirit. Perhaps, they didn't, Bateson might just not have connected what he was told under different perspectives. He noted the identification of the face as winsumbu in Palimbei, where he also observed an elaborate death ritual, not in Kanganamun (see Bateson 1958, caption to pl.VIIIA).

From what has been documented so far, winsumbu refer to that aspect of human soul, kait, in the living man, probably of paternal origin, that is set free at death and continues to stay around, taking to the woods (Bateson, 1932: 417); they are like a puff of wind. Winsumbu can choose to appear in an outward human-like form, causing

12. Possibly the carved suspension hook, showing a seated female figure with legs stretched out horizontally and also ending in another three spikes emanating radially from the central stem, is related to this mythical image. Each of the spikes or hooks ends in an animal head. The carving was collected by Paul Wirz in 1952 (?), perhaps in Kanganamun village, now in the Museum der Kulturen Basel (inv.nr. Vb 2896). 
all sorts of harm ${ }^{13}$. The other part-soul, kip, is the essence of a human body, sort of glued to the bones and linked to the ground; it seems of maternal origin, carrying the name given by the $w a u$. It has to be released after death to travel to the realm of the spirits of the dead, down river and eastwards, linked to underground and water (Schmid and Kocher-Schmid, 1992: 20, 88; Bateson, 1958: 232-233) ${ }^{14}$. Looking at faces identified as belonging to/associated with a wider potential winsumbu class, the motif of the small eye balls set against wide superimposed concentric planes seems most conspicuous ${ }^{15}$. The link to the wakin is possibly established through the winsumbu heads mounted on supporting structures to be shown to the non-initiated public above a screen, which are implicitly associated with the wakin (Bateson, 1958: caption to pl. XXVII). These heads consist basically of over-modeled ancestral skulls, and their supports refer to the $m b w a-$ tnggowi structures used in mortuary rituals (Bateson, 1958: pl. XXIB, XXV; Schmid and Kocher-Schmid, 1992: 70-71; Schindlbeck, 1981; Wassmann, 1991: 74-76). They indeed seem to echo, with the row of pearl shells hanging below them, somehow the image of a hook figure supporting the head, with the gift of mother of pearlshells, calling the wakin spirits in to support the humans, as in the explicit version from Soatmeli (cf. above p. 182). According to Bateson's knowledge the mbwatnggowi ceremonial dolls function indeed as wakin (Bateson, 1958: 233). With the help of wakin, the men keep the village alive and mighty. Hence the Iatmul's reference to the effect of the appearance of the winsumbu on fertility (Bateson, 1958: caption pl. XXVII).

\section{Objects that embody}

Establishing a first visual relationship between your child and these mighty beings of the origins seems no little task. The mother in her private naven to her baby boy identified herself with her ancestral appearance, interrelating naven gestures with carvings of the wakin cum winsumbu type. We might like to ask whether further examples of objects which show up in the context of naven-bound relationships could be identified and described. In naven performances for children on their way to adulthood, it is boys who receive more explicit attention, especially after initiation is completed. Individuals of both genders when enacting the ceremony either enhance their roles by using objects normally used by persons of the opposite gender, or they are alternatively overplaying their own gender by performing (almost) naked.

While naven ceremonies refer to a realm, which links the public to the private - in as far as they normally seem to mark the return of a person from a first time achievement of a specific type in her or his life-, another aspect should not be overlooked. They also serve in rounding up rituals of different kinds held at the ceremonial house as the village's spiritual center. Again, it is the return to the mother, which triggers the naven.

Of course, the most important occasion is the young initiate's return to his mother, once the complex scarification and teaching rituals are completed. Initiation has separated him forever from his mother, nyame, making his mother's brother, wau, to become more important as a source of knowledge and of comfort during the most painful phase of initiation. Through cutting patterns of scars into his skin the initiating moiety made him then to loose a lot of blood.

By interfering with the healing process the scars were intended to heal only slowly; thus eventually the pattern could be enhanced, remaining visible all along the initiate's life. So, returning from this and many other probes he would have become a new person in many ways, yet he is made to return in a highly formalized way, imposing a last probe of extreme endurance in public onto him. He has to stand up for hours, without moving, in front of (or leaning on?) a carved stick which showed a small ancestral face, his gaze directed to the ground, and fully exposed to sunshine and heat. Close to him, on the ceremonial ground outside the initiation enclosure his mother and other women are performing their dances of joy. Only once his ordeal is finished, and the newly initiated man has returned home, the wau (real and classificatory MB)

13. For the Nyaura - or western Iatmul-, Wassmann distinguishes between winjumbu, well-disposed and helpful spirits of the woods, and wundumbu, ghosts or spirits of the dead, who remain near the grave before they float to the land of the dead, to become ngambia; the kait is the soul which wakin try to lure out of an individual's body to kill the victim (Wassmann, 1991: 18, 39-40). For the Central Iatmul the realm of death (undumbu) is undumbu ngei, the «apparitions of recently dead people» are kaiyik, ghost. Life (yuphut) and death are brothers for the Iatmul, life the elder, death the younger (Moutu n.d.: 5).

14. Bateson here mentions that the third «aspect of his [a male individual's] personality which is represented by his secret name...becomes a potsherd spirit [angk-au], a guardian of his clan.» (Bateson, 1958: 233, 307).

15. $C f$. the engraved face on a lime container from gourd, annotated by Bateson (n.d.) on his photograph reproduced here as Photo 7. 
and later the yau (father's sisters, real and classificatory FZ) will start their parts in a naven role play. Here the mimicking of gendered roles serves as much as entertainment as it explains what is happening in an emotion-laden event on the individual level. It is the yau's performance that will come to a peak, when the women (yau, FZ) acting as men will challenge the wau, the mother's brothers acting as women, about their sexual identity: they pretend it was them, the father's sisters (as paternal clan) who had given the wau, the mother's brother acting as mother, the vagina. In return, the latter claim to have given the father the penis. It adds up to enhancing the instrumental part given to the mother in bodily producing the child that now has just returned with glory. The play evidently also helps to reduce potentially disruptive effects between the exogamous lineages. The short concluding act of the wau honoring and shaming in one gesture - rubbing his buttocks down the laua's shine-bone - is a side act, not the focus of public attention.

First of all, one might recall that a wau is disguised in worn, shabby female garments: a skirt and a rain cap. He is also equipped with such female gear as a short pointed paddle, a carrying bag for fried sago cake, a basket or fish-trap for collecting prawns, a fishing net, a spear thrower (for spearing eel, a job for women going fishing) and an adze or a digging stick. These objects make look the male individual performer (or the group of classificatory identical individuals acting this role in public) as seasoned mother(s). The number and quality of gendered objects used in the performance points to their role of enhancing rather than disguising.

The father's sisters, yau, in turn would wear male attire such as a minimal string girdle or a warrior's apron, more recently a European type hat, and carry a lime container with a long spatula and a spear to actively pose as male participants. The performers of male roles would paddle in standing in the canoe, those of female roles in sitting ( $c f$. Bateson, 1958: pl. VIA). Even such male gendered objects as masks could become part of the outfit for a woman (a yau?) performing naven: Magindaua reported about her earlier naven activities, which included participating together with another woman as yau (FZ) «in men's clothes. We played guitar, danced and sang. An old woman put a pig mask on her head...» - probably of a type used by boys and young men (Weiss, 2006: 58; cf. Kelm, 1966, I, $\left.\mathrm{n}^{\mathrm{o}} 85,87\right)$. All of these objects are borrowed for the duration of the performance, and remain the property of their original owners, mostly the opposite sex siblings. Acting out the naven scenes without the gendered objects would make the task of the actors impossible, because without the markers for transvestite behavior acting could nor be explicit, nor dramatically efficient. It is meant to entertain, and to be touching, e.g. when the male performer identifies so completely with the opposite gender, that the audience is seized by the temporary transformation (see Houseman and Severi, 1998: 52 for a description by Stanek).

The use of everyday objects is in line with the fact, that basically naven ceremonies are always public ceremonies, not part of the male ritual sphere. However, in former times, the most prestigious naven ceremonies were played out after large men's house rituals, and, in their most spectacular form, at the moment, a successful warrior and head hunter returned home. Even a wounded warrior, unable to walk, would have to be carried over the lying rows of his naked classificatory mothers, nyame (i.e. the mother's clan sisters or matrilineal cousins), and tshaishi (elder BW) or yau (FZ), and thus be honored (Schmid and Kocher-Schmid, 1992: 78; Hauser, 1977: 96, $155)^{16}$. And a trophy head would indeed be treated as a powerful object to be physically brought into contact with the most sacred, i.e. directly ancestral parts of the ceremonial house, as there are: the ground, the mound in front of the house, the house posts and the wakin slit gongs (Schmid and Kocher-Schmid, 1992: 77-78). Following the report by Bateson's informants on practices of the then pre-1929 past, the head was taken over from the warrior by the wife of the classificatory wau, mbora, dressed as an old woman and carried suspended from her neck; she too would receive a Turbo shell tied to a spear in exchange (Bateson, 1958: 19-20). In a photograph of a wau performing for a group of young laua, a wau disguised as a mother dancing is carrying an over-modeled head said to represent a trophy head taken by one of his laua (Bateson, 1958, pl.VA). Following Juillerat and Houseman we may identify in the preceding act of the successful warrior, i.e. to present upon returning to the village the severed head first to his mother, as the ultimate reason - the only objectified return gift

16. Bateson refers to this row of lying naked women as «all the women» of the village, who, however, exclude explicitly ego's sister and his wife (Bateson, 1932: 278, 1958: 20). The successful warrior after performing the same stepping over the naked women then was enticed to spear the large pear-shaped prawn-trap, implicitly associated with a vulva (Bateson, 1958: 21). 
a son was able to produce - for triggering a naven ceremony (Juillerat, 1999: 159; Schmid and Kocher-Schmid, 1992: 79). Again, the ceremony makes sense only if and as long as the head as an object is available; it is irreplaceable. A dead enemy's head is the ultimate manipulable objectification of ancestral life force.

\section{Embodiment as a service rendered}

A male child in his role as laua is to obtain general ritual or initiatory knowledge partly from his maternal uncle, wau, albeit mainly from one of the classificatory wau. As far as we know, the laua (ZS) owes his wau (MB) compensatory gifts each time he is being shown or imparted some knowledge (shell valuables, formerly tied to a spear). The laua owes his wau also some services, especially as a dancer, i.e. as an animator of mask costumes carrying mask faces owned by the wau and his paternal clan lineage.

In a ceremony arranged on the central dance ground (wompuno), recently initiated men are activating the mai (or mwai) masks that make their appearance in minimal groups of three, two brothers and one sister. The «mother of all the maì, with a flatter face (?), named Tambioli in Palimbei, appeared a few days earlier, quite alone. In fact, if a wooden mai head is not available, it is, as with other clan specific ancestral figures, the laua's obligation to carve one, and to present it to his wau; only then would it be mounted on a costume (Bateson, 1958: 45; Herle and Moutu, 2004: 33). The masked dancers arrive and perform in sight of a crowd by leaving a specially fenced space (ndimba). Without the fence there would be no hiding of who puts on which mask. In any case, it should be men in a laua (ZS) role to the owners of the mask that dance with the mai costumes. Performing the masks announces the social fact that the former initiates have now reached the stage of being mature. It also reveals that the founding ancestors are still in command of their minor forms of life appearance or embodiment. Indeed, according to a traditional Iatmul view, the mai masks are the junior version of the large wakin figures appearing over night for a public ceremony in front of the ceremonial house (Bateson, 1958: pl. XVIIIB and XXVIIIA).

Thus, on the other hand, the laua, according to the information Bateson received, is the live embodiment of his maternal clan's ancestors: he has ingested on repeated occasions the food, which was offered as a sacrifice to the ancestors

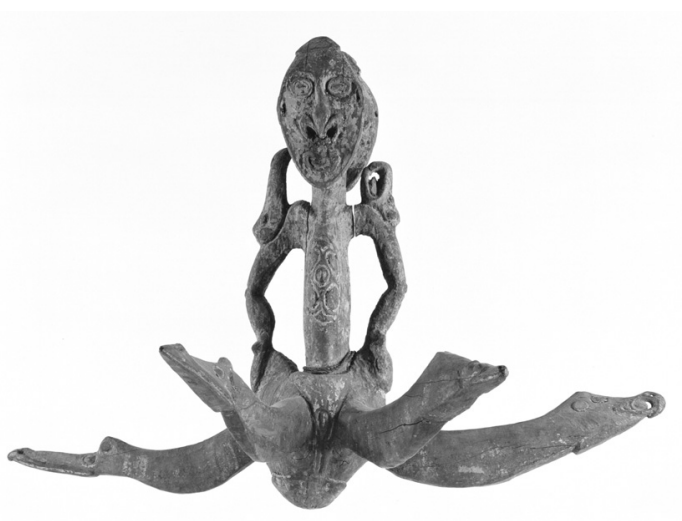

Рното 6. - A suspension hook of exceptional shape, said to come from a ceremonial house in the central Iatmul area; the suspending spikes end in snake (or bird) heads. This iconography is highly suggestive of a link to the myth of the original wakin snakes coming out of a tree (CMuseum der Kulturen Basel, collection Paul Wirz 1952, inv.nr. Vb 2896)

of this clan by hanging it up on the dedicated suspension hook (Bateson, n.d. on hook Cambridge 35.62); he will even «eat his maternal ancestors», e.g. when he is given doubled eggs of crocodile to eat (Bateson, 1958: 45-47). By playing the flutes of his maternal clan he also relates the voice of the maternal ancestors. The wau addresses his laua (and so does vice versa the laua his wau) indeed as «Nyai' nggwail», Ancestor, literally «father and father's father».

Certainly, one of the most spectacular services a laua (ZS) could have rendered to his wau (MB), was performing with the latter's clan abwan mask, the so-called Small abwan (if we follow Weiss's analysis, [Weiss, n.d.]), consisting of a visually very attractive costume, showing two superimposed and often divergent personality renderings. This mask costume would normally have been produced by men of one of the neighbouring Sawos villages in a plaiting technique using a passive coil and active plaiting strands. This would give the costume stability while keeping it light. The final step consisting of overmodeling the principal face(s) with the yimba paste as well as painting them, would have to be achieved by the hands of a Iatmul male. The two superimposed personalities can be either a face mask face plus a second head, integrated into the basketry costume (alternatively an overmodeled skull), or it could consist of a lower face and a separate being, usually a totemic bird standing or sitting on the top of the costume (Bateson, 1932: pl. VII right, Mevambül-awan of Mwailambu clan in Mindimbit). Normally, clan specific abwan masks were kept in private houses. 


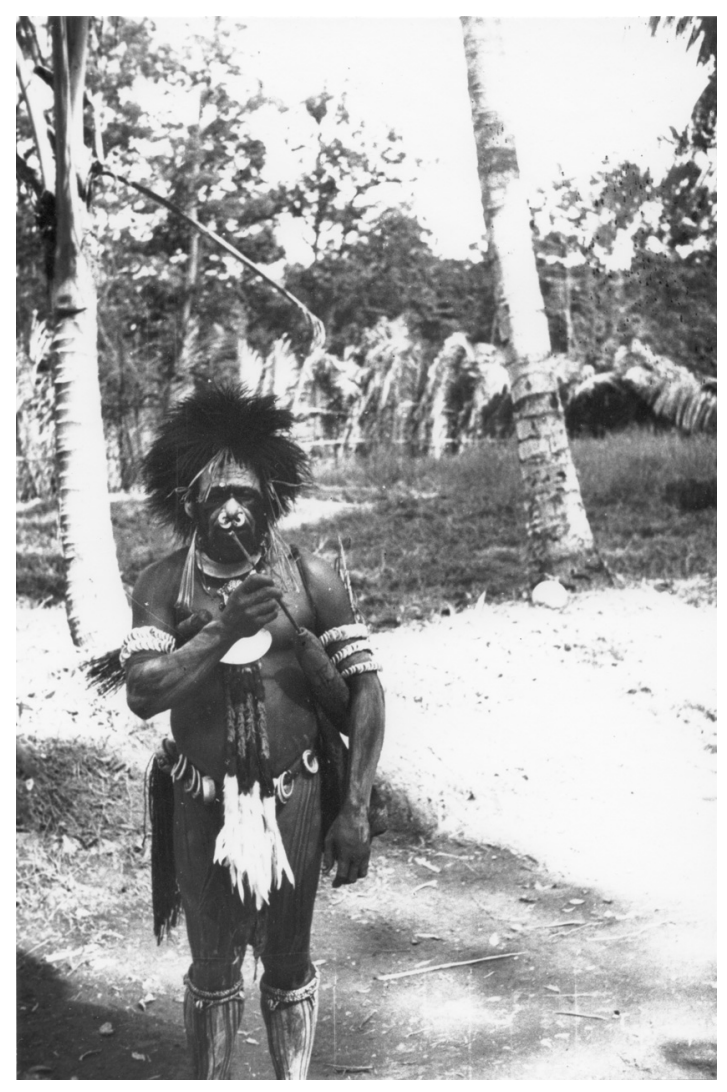

Рното 7. - A fully Iatmul decorated man with his lime container, showing a winsumbu type face (Photo G.Bateson, This image is copyright. Reproduced by permission of University of Cambridge Museum of Archaeology \& Anthropology, acc.no. P.16630 BAT)

They were definitely more fragile than the Big abwan costumes ${ }^{17}$, the latter intimately linked to the ceremonial house (ngeko) and to rites which were part of the initiation.

As to the name of these masks there is some confusion ever since Bateson. Abwan (Bateson wrote awan) denotes the two types of mask, which have, to all appearance, only little in common, and abwan is also the suffix used in ancestral names to denote that the name in question belongs to a maternal ancestor (or has its origin in the name pool of a maternal line). That mask costumes, which have to be activated by the classificatory sisters' sons or laua and on which the upper figure evidently links up to a clan's specific ancestry, are generically called abwan as is the laua by his secret maternal name, is logical Whether for the much more mobile Big abwan masks a similar, metaphorical ancestral link could be established remains to be seen.

To think of these public performances of a laua in disguise in a mask costume as being the equivalent of his wau's public performances,

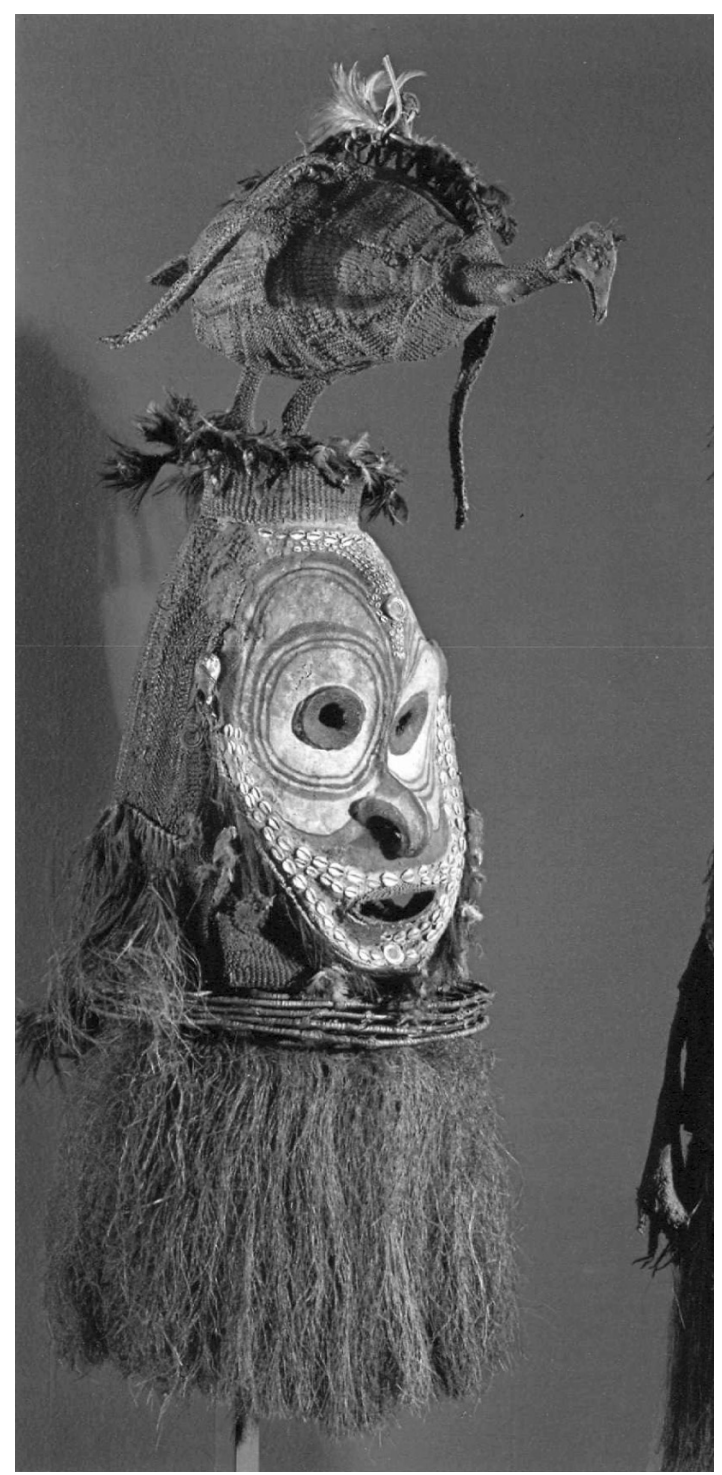

Рното 8. - Costume of Mevambül-awan, Mwailambu clan in Mindimbit, as identified by G. Bateson in 1929 (CMuseum der Kulturen Basel, coll. Dadi Wirz 1955, inv.nr. $\mathrm{Vb} 22114$ )

seems a valid observation, especially considering the latter's moving gesture of rubbing in public his buttocks against the shine-bone of his laua, thus shaming the laua by evoking the female other in him (Juillerat, 1999: 174-176). Performing, the laua, a fully initiated man, embodies the ancestors of the clan of his mother and of his wau, so he is coming back in a very spectacular way to his origins: the look of the mask-person's calm, individualized and humanized expression certainly gave the display overwhelming visual power. For all involved a moment of fulfillment. It is the junior who, with all his life force, is bringing the dead skin or costume (shaba) into 
life on village stage, a stage which is open to public visual perception. It is also a stage upon which ancestral forces might directly enter the performing skin or costume, making their presence known by some significant, yet barely visible sign, a puff of air, a movement of one of the head ornaments.

In former times it would also have been the laua who would have performed with the winsumbu heads mentioned earlier in a special ceremony, called kwangumeli mbangu in front of the men's house. Its function would have been to concentrate spiritual forces in e.g. important new parts of a ceremonial house or in a new communal canoe by «heating up» the object (Schmid and Kocher-Schmid, 1992: 72). For this occasion again, like for the initiation rituals, a fence, ndimba, would have to be built around the ceremonial house. At the concluding step again a rather large naven was to be held for all the performers (Bateson, 1958, pl. XVIIIB and XXVIIIA, Schmid and Kocher-Schmid, 1992: $72-73)^{18}$.

We can now see that in naven relationships much weight is given to displaying knowledge through objects as well as through bodily gestures. Under both aspects it is the gendered meaning of the objects as well as of the activating gestures that defines the focus of the display. After all, we should perhaps note that, according to Weiss (2006: 62), the literal translation of na-ven would be «Look at this!» or more directly «hey, this, here!» (na-) [you are] «looking at» (ve-).

\section{Balance of services and the establishment of bonds}

Seen from the outside it seems that the gifts of knowledge made visually available and the equally non-material gifts of services rendered by performing for the good of either the laua or the wau are in balance. There seems however to be a second level to the relationship where services rendered by the wau, and more especially hidden verbal knowledge imparted had, at least according to custom in some villages, to be countered by material gifts in the form of shell valuables (Bateson, 1932, 1958; Houseman and Severi, 1998). These valuables would have to be passed from the laua (or his paternal clan relatives) to the wau, in exchange for the latter's gifts knowledge and/or services, which would include the classificatory wau's important role in nurtu- ring and protecting his laua during scarification, teaching and recovery. As we have remarked upon, the payments of shell money at marriage to the lineage of the bride would not go to individuals potentially fit to serve as classificatory wau; therefore additional gifts (in the general sense of gifts in exchange) would become necessary. It is in line with this logic that according to the only description available of a wau's naven for a girl, it were the wau (classificatory MBs) bringing pigs, thus marking their obligation to their classificatory sister's husband (tawontu), but in view of obtaining shell valuables as a counter-gift (Bateson, 1958: 17).

As it is Iatmul women who still provide in daily life the traditional food - fish and sago - for all to eat, male Iatmul individuals as e.g. laua receive and eat, or received and ate according to Bateson, ceremonial food that is given to them by the maternal clan through their wau. They owe in a way their live bodily appearance to their maternal ancestors, yet their personality (and their bones) to their father and grandfather.

In fact, all the gifts of services, food and goods taken together tighten markedly the link between the individual as a member of a specific paternal line and his or her maternal line. If naven ceremonies performed by mothers (and further females) mark first of all the successful return of their children to their mother in her capacity as a member married into the father's clan, the naven ceremony performed by the wau once initiation has been achieved serves an equivalent purpose. The wau's performance marks the return of the reified, now solely male body of the laua, or indeed of the younger brother to the age group of the elder brother, thus ending the special enactment of the social relationship between wau and laua during the period of seclusion.

In the village environment of the Iatmul past, the underlying bond would have later been reinforced publicly each time the laua helped to revitalize the empty, motionless mask structures of his mother's and the wau's paternal clan, as we have just seen. In as much as the laua can also be classified as the younger brother of the wau, each such clan abwan mask performance also marks, quite in line with Moutu's argument, a return of the younger brother to the elder brother.

An in-depth restudy of evidence for the large communal events involving numerous individual and parallel naven ceremonies following the completion of major ceremonial cycles at the men's house might show that naven rites are

18. In the neighbouring Sawos village of Gaikorobi Markus Schindlbeck and Hermann Schlenker were able to record such a winsumbu performance on film (Schindlbeck, 1981). 
indeed more than clan related ceremonies. It was already mentioned that links between classificatory wau's descending from the same pair of sisters marrying into different clans would establish more formal links for potential cooperation in communal tasks between the clans involved. The entire laua work force of these wau would be activated for carving and building work at the building site of a senior ceremonial house, ngeko (Bateson 1958: 96). And in fact the completion of such a structure would trigger an especially important naven. One wonders whether there were once indeed deeper links between a Iatmul vision of the role of the many individuals involved in any singular naven relationship, including the exchanges of knowledge involved in practicing it, and the Iatmul vision of the cosmological order. We may leave it at that.

\section{Conclusions}

Physical objects, mainly every day gear of a gendered character, do carry additional, yet transformed meaning when handled in a ceremonial context. Reference to or performing with objects in relationships that are part of or lead up to naven ceremonies can be seen as producing unmediated gifts, gifts of knowledge or services. With these gifts it is the visually expressed knowledge transmitted through the display of objects that circulates, not the object. In the very first naven celebrated for a small child not yet able to walk, who for the first time returns to his or her mother, it is the mother who produces the gift by visually revealing that she is one with a dominant ancestor of the place. This gift of visual knowledge would open the way for the child later receiving further knowledge about crucial transformations. In later rites, the main gifts of hidden knowledge reach the child, especially the male child from the mother's brother (wau, mainly the classificatory mother's brother).

The exchange of objects as material things given (or gifts) between the persons directly involved and their groups, including the groom and the bride's real brother, form an important part of marriage ceremonies. On top of this, unmediated gifts of knowledge or services, especially those rendered by a classificatory mother's brother, wau during the sister's son initiation, need to be compensated partly by giving valuables. It seems more important, however, that these services, culminating in dramatic performances by the wau (MB) honoring the laua (ZS), would be balanced out by the laua activating and performing with the mask costumes (mai, abwan) and dance figures (winsumbu) belonging to the wau's clan. Looking at this as a complex of interrelated acts, we may find on the one hand that knowledge made visible through the explicit use of objects in ceremonies stresses the importance of the original maternal transformational role for initiating an efficient individual link to village ancestors. On the other hand, the individual laua (ZS), by repeating his returning to the maternal ancestors in a transformational act of performance or embodiment, maintains the fundamental link, thus triggering in turn a performative response - i.e. a naven performance. In naven ceremonies especially the distinctions between the human body and an object as its gendered extension, between life and performance, between the hidden face and the visible mask, between son and mother or between younger brother and elder brother are intentionally becoming blurred. Yet this blurring is patterned by certain rules. It should occur to the reader that, most probably, there never was a strictly normative Iatmul iconology, yet knowledge, its revelation and its concealment, all are governed by canons, authoritative ideals which call for being interpreted each time a form evoking a transformation is to be recreated.

I am afraid that in my contribution I have raised more questions than I have been able to answer. I deeply regret not having clarified and raised my questions in discussing with Bernard Juillerat - a joint project on Melanesian art having been abandoned before we really got a chance to enter into the matter.

\section{Acknowledgement}

I wish to thank the Sainsbury Research Unit, University of East Anglia, Norwich and especially Steven Hooper, Director, Pat Hewitt, Librarian, Jeremy Bartholomew and Matthew Sillence, Assistant Librarians as well as Lynne Crossland Humphreys and the Faculty staff at the School for World Art Studies and Museology for their hospitality and inspiring support during the spring term 2009. I would also like to acknowledge the support of Antje Denner, Christin Kocher-Schmid, Sylvia PuschnigOhnemus, Brigit Obrist van Eeuwijk, Florence Weiss, Milan Stanek, Juerg Wassmann and Markus Schindlbeck, who all have contributed to the project of documenting and studying Iatmul and Central Sepik material culture over the last 30 years, a project originally located at the Museum der Kulturen Basel, supported by the 
Institute of Ethnology (now Social Anthropology) at the University of Basel, and financed by the Swiss National Research Foundation, a project yet to be completed (see also Kaufmann 1990, Kocher-Schmid, n.d.). Anita Herle and Jocelyne Dudding have greatly facilitated access to the photographs of $\mathrm{G}$. Bateson held at the University Museum of Archaeology and Anthropology, Cambridge, UK. And last but not least, my thanks go also to the anonymous peer reviewers as well as to the participants of the Melanesian Research Seminar at the British Museum in London (March 5, 2010) for their suggestions. All errors are mine.

\section{BIBLIOGRAPHY}

Bateson Gregory, 1958 [1936]. Naven. A survey of the Problems suggested by a Composite Picture of the Culture of a New Guinea Tribe drawn from Three Points of View, Stanford, Stanford University Press.

—, n.d. Middle Sepik - Notes to Show Cases, edited by A.C. Haddon (?), pre-1938. [Contains original notes to selected photographs and all the specimens collected in 1929 and 1932, and preserved in the Cambridge, University Museum of Archaeology and Anthropology].

Coupaye Ludovic. 2009a. Faire l'expérience de l'espace : la frise tëkët des Abelam, Arts\&Cultures 2009, Genève, musée Barbier-Mueller et Paris, Somogy, pp. 210-225.

—, 2009b. What's the matter with technology? Long (and short) yams, materialisation and technology in Nyamikum village, Maprik district, Papua New Guinea, The Australian Journal of Anthropology 20, pp. 93-111.

Godelier Maurice. 1996. L'énigme du don, Paris, Flammarion (1999, English version: The Enigma of the Gift, translated by Nora Scott, Cambridge, Polity Press).

HaUSER-SChäUblin Brigitta, 1977a. Frauen in Kararau: zur Rolle der Frau bei den Iatmul am Mittelsepik, Papua New Guinea, Basel, Ethnologisches Seminar der Universität und Museum für Völkerkunde, Basler Beiträge zur Ethnologie 18.

_, 1977b-1981. Mai-Masken der Iatmul, Papua New Guinea: Stil, Schnitzvorgang, Auftritt und Funktion, Verhandlungen der Naturforschenden Gesellschaft in Basel 87/88 (1976/77), pp. 119-145, and vol. 92 (1981), pp. 47-54.

_, 1985. Der geliebte Mann, die vergewaltigte Frau. Das Beispiel der Iatmul am mittleren Sepik, PapuaNeuguinea, in G. VöLGER und K. V. Welck (eds), Die Braut. Geliebt, verkauft, getauscht, geraubt. Zur Rolle der Frau im Kulturvergleich, Ethnologica N.F. 11 (Teil 2), pp. 520-527.
_, 1986. Ritueller Wettstreit mit Feldfrüchten: Yamsfeste im Sepik-Gebiet, Papua New Guinea, Verhandlungen der Naturforschenden Gesellschaft in Basel 97, pp. 87-102.

—, 1989. Kulthäuser in Nordneuguinea [notably part 2: Vergleichende Studien zu Kulthäusern im SepikGebiet und an der Nordküste], Berlin, AkademieVerlag, Abhandlungen und Berichte des Staatlichen Museums für Völkerkunde in Dresden 43.

-,1995. Puberty rites, women's naven, and initiation: women's rituals of transition in Abelam and Iatmul culture, in N.C. LutKehaus and P.B. RosCoe (eds), Gender rituals: female initiation in Melanesia, New York, Routledge, pp. 33-53.

Herle Anita and Andrew Moutu, 2004. Paired Brothers: Concealment and Revelation Iatmul Ritual Art from the Sepik, Papua New Guinea, Cambridge, University Museum of Archaeology and Anthropology.

Houseman Michael et Carlo Severi, 1994. Naven ou le donner à voir. Essai d'interprétation de l'action rituelle, Paris, Éditions de la maison des sciences de l'homme.

—, 1998. Naven or the other self. A relational approach to ritual action, translated from the French by Michael Fineberg [enlarged version of the 1994 publication], Leiden etc., Brill.

Juillerat Bernard, 1986. Les Enfants du Sang. Société, reproduction et imaginaire en NouvelleGuinée, Paris, Éditions de la maison des sciences de l'homme (1996 English version: The Children of the Blood. Society, Reproduction and Cosmology in New Guinea, translated by Nora Scott, Oxford and New York, Berg).

—, 1991. Edipe chasseur : une mythologie du sujet en Nouvelle-Guinée, préface d'André Green, Paris, Presses universitaires de France.

_, 1999. Séparation, retour, permanence. Le lien maternel dans le rite naven des Iatmul, L'Homme 151, pp. 151-179.

—, 2002a. The other side of the gift: From Desire to Taboo. Representations of exchange and oedipal symbolism among the Yafar, Papua New Guinea, in M. Jeudy-Ballini and B. Juillerat (eds), People and Things. Social Mediations in Oceania, Durham, NC, Carolina Academic Press, pp. 157-183.

Juillerat Bernard (ed.), 1992. Shooting the Sun. Ritual and Meaning in West Sepik, Washington and London, Smithsonian Institution Press.

Kaufmann Christian, 1990. Swiss and German ethnographic collections as source materials: A report on work in progress, in N.C. Lutkehaus et al. (eds), Sepik Heritage. Tradition and Change in Papua New Guinea, Durham NC, Carolina Academic Press, pp. 587-595.

Kelm Heinz, 1966. Kunst vom Sepik - I, Mittellauf, Berlin, Museum für Völkerkunde, Veröffentlichungen des Museums für Völkerkunde Berlin NF 10. 
KoCHER-SCHMID Christin, n.d. Companions in Arms. The ritual system of the Central Iatmul, manuscript [2009], 16 p.

LIPSET David. 1997. Mangrove Man. Dialogics of culture in the Sepik estuary. Cambridge, Cambridge University Press.

MeEker Michael, Kathleen BARLow and David LIPSET, I986. Culture, exchange, and gender: Lessons from the Murik, Cultural Anthropology 1, pp. 1-73.

Morgenthaler Fritz, Florence Weiss und Marco MORGENTHALER, 1984. Gespräche am sterbenden Fluss: Ethnopsychoanalyse bei den Iatmul in Papua Neuguinea, Frankfurt a.M., Fischer Taschenbuch 42267.

-, 1987. Conversations au bord du fleuve mourant: ethnopsychanalyse chez les Iatmouls de Papouasie Nouvelle-Guinée, préface de Georges Balandier, trad. de l'allemand par Monique Picard, CarougeGenève, Zoé.

Moutu Andrew. 2007. Collection as a way of being, in A. Henare, M. Holbraad and S. Wastell (eds), Thinking through Things. Theorising artefacts ethnographically, London and New York, Routledge, pp. 93112.

—, n.d. (2006). Return of the Younger Brother in the Naven ritual. Seminar Paper, Senior Seminar, Department of Anthropology, University of Cambridge, May 12, 2006, manuscript.

Roscoe Paul, 1995. In the shadow of the Tambaran. Female initiation among the Ndu of the Sepik Basin, in N.C. Lutkehaus and P.B. Roscoe (eds), Gender rituals: female initiation in Melanesia, New York, Routledge, pp. 55-82.

SchindlbeCK Markus, 1981. Sawos (Neuguinea, Mittlerer Sepik). Totenfest in Gaikorobi: Anrufung und Tanz der Ahnen, Gesänge und Flötenspiel = Sawos (New Guinea, Middle Sepik). Mortuary ceremony in Gaikorobi: invocation and dance of the ancestors, singing and flute-playing (Encyclopaedia cinematographica, Film E 2481, Hermann Schlenker und Markus Schindlbeck), Göttingen, Institut für den wissenschaftlichen Film, Publikationen zu wissenschaftlichen Filmen. Sektion Ethnologie; Ser. 11, Nr. 6.

—, 1985. Männerhaus und weibliche Giebelfigur am Mittelsepik, Papua-Neuguinea, Baessler-Archiv N.F. 33, pp. 363-411.

_, 1991-1993. Iatmul (Neuguinea, Mittlerer Sepik). Auftritt der «mai»-Masken in Korogo (Encyclopaedia cinematographica; Film E 2346, Hermann
Schlenker und Milan Stanek), Göttingen, Institut für den wissenschaftlichen Film, Publikationen zu wissenschaftlichen Filmen, Ethnologie Ser. 17/18, pp. 121-131.

Schmid Jürg und Christin Kocher-Schmid, 1992. Söhne des Krokodils: Männerhausrituale und Initiation in Yensan, Zentral-Iatmul, East Sepik Province, Papua New Guinea, Basel, Ethnologisches Seminar der Universität und Wepf, Basler Beiträge zur Ethnologie 36.

Silverman Eric, 200 I. Masculinity, motherhood, and mockery: psychoanalyzing culture and the Iatmul Naven rite in New Guinea, Ann Arbor, University of Michigan Press.

STANEK Milan, 1984-2007. Iatmul (Neuguinea, Mittlerer Sepik). Fest zur Kanueinweihung in Kanganamun, Auftritt von Waldgeistern und Ahnfrauen, DVD Video, Film Hermann Schlenker, Milan Stanek prod. 1973, released 1984, Göttingen, IWF Wissen und Medien, 2007.

STRATHERn Marilyn. 1988. The Gender of the Gift. Problems with women and Problems with Society in Melanesia, Berkeley, University of California Press.

Wassmann Juerg, 1991. The Song to the Flying Fox. The public and esoteric knowledge of the important men of Kandigei about totemic songs, names and knotted cords (Middle Sepik, Papua New Guinea), translated by Dennis Q. Stephenson [from German, original title Der Gesang an den Fliegenden Hund], Boroko [Port Moresby], National Research Institute, Cultural Studies Division, Series: Appwitihire: Studies in Papua New Guinea Musics, vol. 2.

WeIss Florence, 1994. Rapport sociaux de sexe et structures socio-économiques dans la société Iatmul, in C. Calame et F. Weiss, Rapports sociaux de sexe et cérémonie du Naven chez les Iatmul de Nouvelle-Guinée: deux études anthropologiques, Lausanne, Institut d'anthropologie et de sociologie, Recherches et travaux en anthropologie 5, pp. 3-55.

_, n.d. Maskenkostüme der Iatmul: Die abwan. Museum für Völkerkunde Basel, SepikDokumentation, manuscript [1984] and microcfiche 3-03.

Weiss Florence and Milan StaneK, 2006. Aspects of the Naven ritual. Conversations with an Iatmul woman of Papua New Guinea, Social Analysis 50, 2, pp. $45-76$. 